\title{
Malignant Granular Cell Tumor
}

National Cancer Institute

\section{Source}

National Cancer Institute. Malignant Granular Cell Tumor. NCI Thesaurus. Code C4336.

An uncommon granular cell tumor which may metastasize to other anatomic sites.

Morphologic characteristics include the presence of spindling neoplastic cells, necrosis,

extensive pleomorphism, prominent nucleoli, and increased mitiotic activity. 